\title{
STUDENT EXPECTATIONS OF TESOL PROGRAMS
}

\section{STUDENT AND TEACHER PERSPECTIVES}

Sarbari Bordia, University of South Australia

Sarbari Bordia is a lecturer in Business Communication for NESB students in the School of Management, University of South Australia. She has a Ph. D. in TESOL Studies from the University of Queensland and an Ed. M, in TESOL from Temple University, Philadelphia, USA.

Lynn Wales, University of Queensland

Lynn Wales is a Senior Lecturer in The School of English, Media Studies and Art History. She teaches in Linguistics and TESOL studies.

Jeffery Pittam, University of Queensland

Jeffery Pittam is a retired Associate Professor from The School of English, Media Studies and Art History. He taught in Communication studies.

Cindy Gallois, University of Queensland

Cindy Gallois is a Professor in the School of Psychology. She is currently the Director of Research, Faculty of Social and Behavioural Sciences.

Most practitioners teaching English to speakers of other languages (TESOL) will agree that students come with some expectations about course content and teaching methodology and that these expectations play a vital role in student motivation and learning. However, the study of student expectations has been a surprising omission from Second Language Acquisition research. In the studies reported here, we develop a model of student expectations by adapting the Expectation Disconfirmation paradigm, widely used in consumer psychology. Student and teacher perspectives on student expectations were gathered by interviews. Responses shed light on the nature of expectations, factors causing expectations and effects of expectation fulfilment (or lack of it). The findings provide new avenues for research on affective factors as well as clarify some ambiguities in motivational research in second language acquisition. The model presented here can be used by teachers or institutions to conduct classroom-based research, thus optimising students' learning and performance, and enhancing student morale.

\section{INTRODUCTION}

The study of English as a second language in Australia started in the context of teaching English to adult migrants (McNamara 2001) ${ }^{1}$. In recent times, English has also become a language of international importance. Economic globalisation and the spread of multinational companies have prompted a further increase in English language education

Copyright Agency Limited (CAL) licensed copy. Further copying and communication pronitited except on payment of fee per Copy or Comminication and otherwise in accordarce with the licence from CAL to ACER. For more 
(Nunan 2001). Looking at historical and current trends, the study of student expectations seems vital in fulfilling learner's needs effectively. Adult migrants, learning English to obtain employment, provide effective guidance in their children's education and fulfil day-to-day activities in a new country, will have specific expectations from their teaching program based on their individual language learning goals. Apart from migrants, international learners may want to learn English for specific educational or career goals. Many such learners (often adults) travel to English speaking countries and endeavour to learn English within time constraints. Intensive language programs are expensive and run during normal working hours. Therefore learners not only have to make a monetary commitment to an expensive education, they also have to forgo full-time employment (or any employment at all based on visa entitlements). This leads to substantial monetary commitment by learners. Such situations are likely to give rise to specific expectations in learners regarding the process and outcome of language learning and the fulfilment of these expectations may affect motivation and learning. As any social or psychological issue that has a bearing on learning outcomes, student expectations can be seen as an affective factor in Second Language Acquisition (henceforth SLA). However, unlike various other affective factors, student expectations have not received any research attention in language education. The largest share of research on affective factors has been dedicated to the study of motivation in SLA (e.g., Dörnyei 2005; Masgoret and Gardner 2003; Tremblay et al. 2000). Intuitively, fulfilment of student expectations may be directly linked to motivation and performance in language learning.

Given the importance of motivation in successful language learning contexts (Gardner and Lambert 1972), we aim to address the lack of research on student expectations. In this paper we have developed a model of student expectations based upon the expectation disconfirmation paradigm, widely used in consumer psychology. In the development of the model we consider the sources, nature and consequences of expectations. Moreover, we propose that the fulfilment or non-fulfilment of these will have profound implications for student motivation and learning. SLA research has been historically multidisciplinary with influences from a variety of fields (Gass 2001). In a similar vein, our approach on student expectations borrows from extensive work on expectations in the consumer psychology literature.

\section{STUDENT EXPECTATIONS AND MOTIVATION IN SLA}

Gardner's Socio-Educational Model of motivation (Gardner and Lambert 1972) has been the most influential perspective on motivation in SLA. The model is based on the 
integrative motivational orientation of language learners and argues that learners interested in adapting into the target culture will be motivated to learn and will consequently be successful learners (e.g., Csizer and Dörnyei 2005; Dörnyei 2005; Masgoret and Gardner 2003; Tremblay et al. 2000). This model has been supported by several studies (e.g., Clément and Kruidenier 1985; Gardner and Lambert 1959; Gardner and Lambert 1972; Lalonde and Gardner 1984). However, other studies have failed to obtain support for this model (e.g., Gardner and Santos 1970; Lukmani 1972; Oller et al. 1977a; Oller et al. 1977b). Upon a closer look at the latter, it is evident that all of them were conducted in geographical areas where learners learnt the language for uses other than cultural and linguistic adaptation, e.g., economic benefits in the Philippines (Gardner and Santos 1970), the language of former rulers in India (Lukmani 1972), the language of political and economic oppressors for Mexican-Americans in New-Mexico (Oller et al. 1977a) and educational purposes for Chinese graduate students in the US (Oller et al. 1977b). It is likely that these learners had different expectations from the learners in dual-linguistic and cultural contexts in Quebec, Canada and Louisiana, USA, where research on motivation was more supportive of the model. If student expectations had also been looked at in the above mentioned studies, less ambiguous results might have been obtained.

Such ambiguities in results have led researchers (Au 1988; Belmechri and Hummel 1998; Crookes and Schmidt 1991; Dörnyei 1994; Oxford and Shearin 1994; Spolsky 2000 ) to critically evaluate Gardner's theory and direct future researchers to alternative paths of exploration. These researchers have pointed at other areas of psychology (organisational and developmental) and education (general and first language learning) for a broader framework of research in SLA motivation. Research on student expectations based on a model used widely in consumer psychology, is therefore in line with this relatively new trend of rethinking motivation in SLA.

\section{EXPECTATION DISCONFIRMATION PARADIGM}

Expectations of consumers have been widely researched in areas of product-marketing (e.g., Frank 1968; McKinney et al. 2002; Miller 1977; Ross et al. 1987; Santos and Boote 2003), service-quality (e.g., Parasuraman et al. 1985; Parasuraman et al. 1988; Tan and Kek 2004) and health-care-marketing (e.g., Martin 2003; Noyes et al. 1974; Ozge 2001; Ross et al. 1981). This research, guided by the Expectation Disconfirmation paradigm (Figure 1), notes that the fulfilment of expectations strongly influences satisfaction with the product or service. According to this paradigm, expectations are compared with performance of the product or service and result in confirmation (i.e., fulfilment) or 
disconfirmation of the expectations. Confirmation happens when the product or service performs as expected and leads to satisfaction. Disconfirmation (or a mismatch between the expectations and performance) can be positive or negative. Positive disconfirmation happens when the performance is better than expected and leads to enbanced satisfaction. Negative disconfirmation happens when the performance is less than expected and leads to dissatisfaction.

While there are many obvious differences between consumer expectations and those of English as a Second Language (henceforth ESL) and/or English as a Foreign Language (henceforth EFL) students, there are some significant similarities. Students (especially EFL students), spend a substantial sum of money in learning English. They also want the acquired knowledge to meet certain needs. Based on their needs or language learning goals, students would expect to learn certain aspects of the language more than others. This is similar to consumers who acquire a product or service to meet specific requirements.

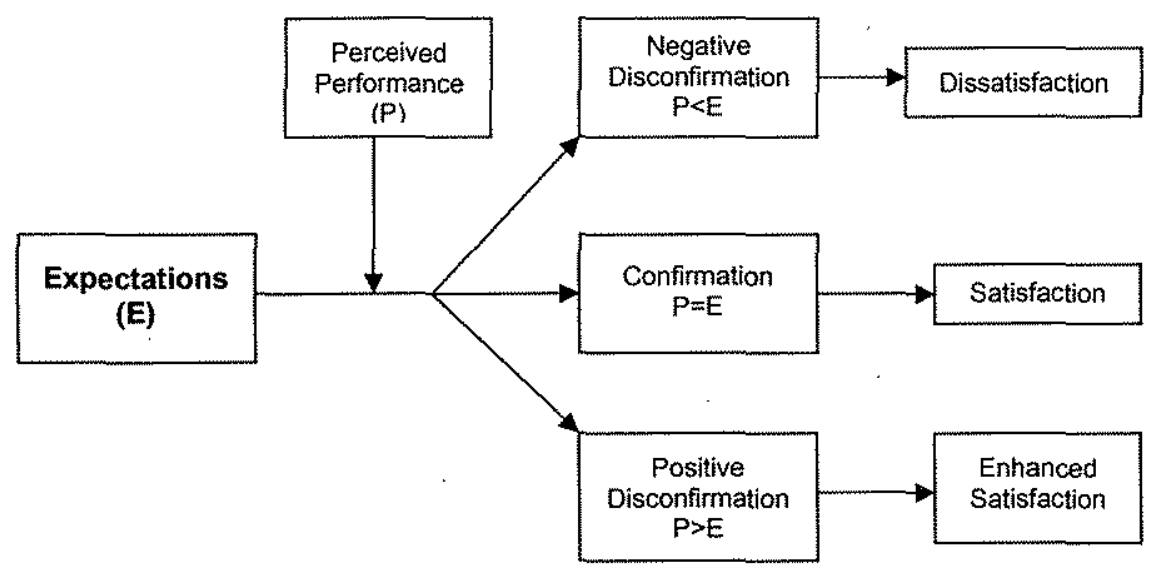

Figure 1 Expectation Disconfirmation paradigm

Patient and client expectations from health care services also have similarities with student expectations. While patients are dependent on health care personnel for treatment and recovery, they do come with certain expectations regarding the process and outcome of the treatment. Similarly, while dependent on teachers, researchers and the institution for acquisition of knowledge, students do have preconceived expectations from courses. 
In second language learning, student expectations may be based on previous language learning experiences and future goals and needs. Also, satisfaction may not be the only outcome of disconfirmation. Disconfirmation of expectations may affect student motivation, performance, behaviour in class and the general language learning experience. Therefore, in order to meet the needs and parameters of second language learning, the Expectation Disconfirmation paradigm needs to be modified to include variables that may be instrumental in shaping expectations and a range of outcomes of disconfirmation. The current research aims to acquire an understanding of the nature and consequences of student expectations and develop a model of student expectations in the TESOL context.

A set of five research questions guided this research and they are as follows:

1. Do students have pre-conceived expectations about TESOL courses?

2. What factors shape these expectations?

3. What are the outcomes of negative disconfirmation of expectations?

4. What are the outcomes of positive disconfirmation and confirmation of expectations?

5. What other factors affect satisfaction in TESOL programs?

We address these research questions in two studies. Study 1 involved short exploratory interviews of ESOL students and teachers. Based on the responses of these interviews, in-depth interviews of a larger number of ESOL students and teachers were conducted in Study 2. Given the exploratory and model building aims of this research, qualitative methodology was used. This methodology has been widely used in applied linguistics and other social science research, including in the elicitation of client expectations in service quality (Parasuraman et al. 1985; Parasuraman et al. 1988). Qualitative methodology encourages participants to introspect on the process of learning, which is a major goal of SLA research (Gass 2001). It also draws responses that help researchers '...understand human behaviour from the actors own frame of reference...' (Nunan 1994, 4). This was important for the current studies which looked at an issue with no prior research directly dedicated to it. Both the studies investigate research questions 1,2 and 3. In addition, Study 2 addresses research questions 4 and 5. As Study 2 replicates and extends Study 1 , the method and result sections have been presented together. 


\section{METHOD}

\section{MATERIAL}

Interview protocols (Appendix $A$ and $B$ ) for students and teachers were designed to elicit the nature, antecedents and consequences of expectations in Study 1 and 2 . The protocols consisted of several open-ended questions regarding the nature and sources of expectations as well as outcomes of non-fulfilment of expectations. In addition, Study 2 included questions investigating consequences of confirmation and positive disconfirmation of expectations, effect of expectations on student motivation and factors affecting general satisfaction.

In order to work within the interpretive research tradition (Nunan 1994), the interviews were semi-structured in format. The protocols were not shown to or distributed amongst participants. The questions included in the protocol intended to start the discussion on the topics but not to inhibit spontaneous responses on issues not previously considered by the researchers. Students were asked to think in terms of the courses they have taken in the current or other similar institutions and teachers were asked to talk in terms of their experiences in ESOL teaching.

\section{PARTICIPANTS AND PROCEDURE}

\section{STUDENT INTERVIEWS}

In Study 1, interviews were conducted with 6 students ( 3 male and 3 female; average age $=26.25 \mathrm{yrs}$.). These students were from an intensive English language teaching centre attached to a University in Brisbane, Australia. Four of the students were Thai and two were Indonesian nationals in Australia to learn English. The students were reluctant participants in one-on-one interviews. Therefore, to reduce apprehension and encourage participation and expression of views, the interviews were conducted in small groups. Three students were enrolled in levels two, three and four respectively of general language classes (the institute has levels from 1 to 6), two were enrolled in a course on English for Academic Purposes and one in English for Academic and Business Conversation. The interviews lasted an average of one hour.

In Study 2, 20 students ( 12 male and 8 female; av. age $=23$ yrs.) from two intensive English language teaching institutions were interviewed. As these interviews were indepth and required participants to demonstrate relatively sophisticated linguistic and communicative competence, students from advanced levels of the institutions were invited to participate. The subjects were from levels 5 and 6 (the institutions have levels from 1 
to 6). They came from Taiwan, Japan, Brazil, Korea, Indonesia and Columbia and were learning the language for further education or better job prospects. Subjects were inter* viewed in pairs of their choosing, hence there were ten interviews (av. time $=35$ mins).

\section{TEACHER INTERVIEWS}

Five teachers were interviewed ( 4 female and 1 male) in Study 1 . All except one had more than ten years of experience in teaching ESL/EFL in various institutions, both within Australia and abroad (mainly Asia). The interviews (av. $30 \mathrm{mins}$ ) were completed within a two-week period.

Ten teachers ( 6 female and 4 male; av. teaching experience $=14.15$ yrs.) were inter viewed individually in Study 2. They had taught in countries such as Taiwan, Japari, Hong Kong, Guyana, Colombia, Mexico, Finland, China, Saudi Arabia, Brunei, England and Australia. Their experiences ranged from teaching basic to advanced TESOL courses, courses in public and private schools, ESP, army, divinity and teacher training colleges. The teachers originated from and were trained in the UK, USA and Australia. Each interview lasted an average of 50 minutes.

Interviews in both studies were audio-taped. In Study 1, the responses were contentanalysed and themes were developed based on subject responses. In Study 2 , the interviews were transcribed and formatted according to the specifications of NUD-IST ${ }^{2}$ by processing of indexing searching and theory-building, and content-analysed with the help of this software. NUD-IST assists qualitative research by extracting codes from transcripts and allowing researchers to combine them under nodes prepared before the analysis or as it progresses. These nodes can be free or hierarchical in nature. The responses from this study were analysed under student and teacher nodes.

\section{RESULTS}

The results of both studies have been presented together and responses are indicated to be from Study $1(\mathrm{~S} 1)$ or Study 2 (S2) in the tables. Results have been presented under the following themes: nature of expectations, factors influencing expectations, outcome of confirmation and disconfirmation (positive and negative), effect of expectations on student motivation and factors affecting satisfaction with the language learning process. On most issues, student and teacher responses have been discussed separately except in the cases of negative disconfirmation of expectations and factors affecting satisfaction where responses from both groups were similar and have been presented together. 


\section{THE NATURE OF EXPECTATIONS}

\section{STUDENTS}

Student expectations covered two broad domains: content, and teaching and learning styles. Table 1 lists these expectations with the number of responses from Study 1 and Study 2 in parentheses.

\begin{tabular}{|c|c|}
\hline $\begin{array}{l}\text { Expectations related to content of } \\
\text { course }\end{array}$ & $\begin{array}{l}\text { Expectations related to teaching } \\
\text { and learning styles }\end{array}$ \\
\hline 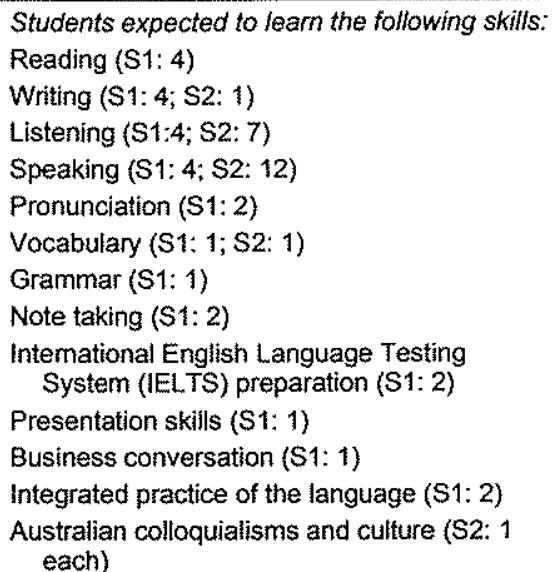 & $\begin{array}{l}\text { Communicative activities (S1: } 2 \text { ) } \\
\text { Group work rather than pair work (S1:4) } \\
\text { Structure of writing (S1: 1) } \\
\text { Individual writing activities (S1: 1) } \\
\text { Group writing activities based on shared } \\
\text { ideas (S1: 2) } \\
\text { Generalised expectations at the onset of } \\
\text { the course (S2: } 7 \text { ) } \\
\text { Expectations regarding specific skills at } \\
\text { the onset of the course (S2: 13) } \\
\text { More expectations from Australian } \\
\text { institutions than from those in home } \\
\text { countries (S2: 19) }\end{array}$ \\
\hline
\end{tabular}

Table 1 Nature of student expectations elicited from student participants $\mathrm{S} 1=\mathrm{Study} \mathrm{t} ; \mathrm{S} 2 \approx \mathrm{Study} 2$

As can be seen, students' expectations were reflective of immediate as well as future professional goals. Participants were aware of the skills they needed to learn in order to survive in educational and corporate institutions (e.g., listening, speaking, presentation skills). They also had expectations relating to their ability to settle and socialise in Australia (culture and colloquialisms). Students expressed their preferences on methodological issues as well (e.g., group work, communicative activities). Perhaps the most sophisticated expectation relating to classroom management and curriculum design was expressed when one student in Study 1 stated that classes should be based on language learning goals so that teachers could create lessons of common interest to students. In Study 2, students had more expectations from Australian institutions than they did from 
those in their home country. Two students attributed this to the lack of maturity and rigidity in secondary school curricula in their own countries. Students reported having generalised rather than specific expectations at the onset of the course. It is possible that learners feel safer having global expectations initially and that specific expectations may arise only after exposure to the course. Perhaps the most beneficial realisation was that language learning takes time and effort ( 6 students).

\section{TEACHERS}

In Study 1, three teachers felt that students in specialised courses have well defined expectations. According to one teacher students have different kinds of expectations from Australian institutions than they would in their own country (e. g., listening, speaking, individual attention and smaller classes).

All teachers stated that students do not always voice their expectations and the ones who do, usually do so towards the middle of the term. According to one teacher, some students do so after they get to know the teacher well. 'Goal-driven and higher-level students express expectations', said another. 'In special courses, needs analysis, ongoing checks and course evaluations are done to give students a chance to express expectations', stated another.

In Study 2, one teacher mentioned that negotiating expectations and curriculum usually facilitates optimal learning environment in class. Students learn items from the curriculum as long as it is linked to their expectations ( 2 teachers). Students often have unrealistic expectations such as taking IELTS $^{3}$ from lower levels, asking how many grammar rules there were in English and expecting to learn quickly because they were being taught by native speakers ( 1 teacher). If not counselled on time, this may lead to emotional and learning detriment for students and business/reputational loss for the institution. With time, said 4 teachers, unrealistic expectations develop into realistic and attainable ones.

\section{FACTORS INFLUENCING EXPECTATIONS}

Responses from both studies are summarised in the following tables for student and teacher responses. In Table 2, student responses along with the number of participants that suggested them in each study are grouped under three broad factors. Educational and cultural experiences affecting expectation development is the first factor that includes responses generating from previous language learning experiences and future educational and cultural needs. Students' expectations based on language learning goals (educational, career and recreational) is the second factor. Expectations generated from financial 


\begin{tabular}{|c|c|c|}
\hline $\begin{array}{l}\text { Educational and cultural } \\
\text { experiences }\end{array}$ & $\begin{array}{l}\text { Language learning } \\
\text { goals }\end{array}$ & $\begin{array}{l}\text { Financial and social } \\
\text { pressure }\end{array}$ \\
\hline $\begin{array}{l}\text { Emphasis on the four } \\
\text { essential skills and not } \\
\text { grammar, as it was taught } \\
\text { extensively in home } \\
\text { country (S1: } 4 \text { ) } \\
\text { Specialized training on } \\
\text { academic and professional } \\
\text { usage as they were } \\
\text { neglected in previous } \\
\text { language training (S1: } 4 \text { ) } \\
\text { Developing a knowledge of } \\
\text { the Australian cuiture } \\
\text { (S2: } 8 \text { ) } \\
\text { Enjoying the English speaking } \\
\text { media (S2: } 8 \text { ) }\end{array}$ & $\begin{array}{l}\text { Future educational plans } \\
\text { (S1: } 5 \text { ) } \\
\text { Better job prospects in home } \\
\text { country (S1: } 3 ; S 2: 12) \\
\text { University education (S2: } 1 \text { ) } \\
\text { International status of } \\
\text { English and effective } \\
\text { communication with a } \\
\text { global audience } \\
\text { (S1: } 1 ; \text { S2: } 7 \text { ) } \\
\text { Travel to and effective } \\
\text { communication in other } \\
\text { countries ( }(1: 1 ; S 2: 7) \\
\text { Making social contacts with } \\
\text { other nationalities (S2: } 3 \text { ) }\end{array}$ & $\begin{array}{l}\text { Return for expenses } \\
\text { incurred (S1: } 1 ; \mathrm{S} 2: 12) \\
\text { Family and peer pressures } \\
\text { (S1:2;S2: } 3 \text { ) }\end{array}$ \\
\hline
\end{tabular}

Table 2 Factors influencing expectations elicited from students S1= Study $1 ; \$ 2$ = Study 2

\begin{tabular}{|c|c|c|}
\hline Educational influence & $\begin{array}{l}\text { Social and institutional } \\
\text { influence }\end{array}$ & Personality traits \\
\hline $\begin{array}{l}\text { Older students have specific } \\
\text { expectations as they are } \\
\text { experienced learners and } \\
\text { have clear career and } \\
\text { language learning goals } \\
\text { (S1: } 2 \text { ) } \\
\text { As perfomance improves, } \\
\text { expectations become more } \\
\text { specific and realistic ( } \mathrm{S} 1: 2 \text { ) } \\
\text { Due to nature of courses, } \\
\text { lower level students may } \\
\text { have less expectations } \\
\text { than those in higher level or } \\
\text { specialized courses (S1: } 1 \text { ) } \\
\text { Teaching styles encountered } \\
\text { in previous language } \\
\text { courses in home country } \\
\text { and Australia affect } \\
\text { expectations ( } 52: 1 \text { ) } \\
\text { Students expect items that are } \\
\text { not taught in home country } \\
\text { (S2: } 4 \text { ) }\end{array}$ & $\begin{array}{l}\text { Students from some cultures } \\
\text { have specific expectations } \\
\text { as well as high motivation } \\
\text { (S1: } 1 \text { ) } \\
\text { Students from some cultures } \\
\text { emphasizing deference } \\
\text { avoid voicing expectations } \\
\text { (S1: } 2 \text { ) } \\
\text { Word of mouth } \\
\text { recommendations } \\
\text { influence expectations } \\
\text { (S2: 1) } \\
\text { Institutional marketing and } \\
\text { advertising efforts affect } \\
\text { expectations (S2: 1) } \\
\text { Students take up } \\
\text { expectations of teachers } \\
\text { and peers they respect } \\
\text { (S2: } 1 \text { ) }\end{array}$ & $\begin{array}{l}\text { Anxious and goal driven } \\
\text { students have higher } \\
\text { expectations and } \\
\text { motivation (S1: 1) } \\
\text { Goal-oriented students have } \\
\text { specific expectations } \\
\text { (S2: } 5 \text { ) } \\
\text { Introverts, due to quiet } \\
\text { introspection, may have } \\
\text { more expectations } \\
\text { (S1: } 1 \text { ) } \\
\text { Extroverts may express } \\
\text { more expectations or } \\
\text { manipulate teachers to } \\
\text { teach expected items (S1: } \\
\text { 1) } \\
\text { Personal preferences in } \\
\text { learning styles affect } \\
\text { expectations (S2: } 1 \text { ) }\end{array}$ \\
\hline
\end{tabular}

Table 3 Factors influencing expectations elicited from teachers

$S 1=$ Study $1 ; \$ 2=$ Study 2 
commitment to language learning, and peer as well as parental expectations make the final factor.

Some of the factors mentioned by teachers in both studies were similar to those of students (English as an international language, monetary costs, family pressure and job viability). In addition, teachers had other responses that are grouped in three factors and presented in Table 3. Expectations derived from educational background such as exper ience in language learning, level of proficiency, teaching and learning styles form the first factor. Socio-cultural influence and institutional communication (e. g., marketing and informal recommendations) form the second factor. Students' individual personality traits (e.g., anxiety and introversion) form the final factor.

\section{OUTCOMES OF NEGATIVE DISCONFIRMATION OF EXPECTATIONS}

Several outcomes of unfulfilled expectations were stated by students and teachers in both studies and have been categorized under psychological and behavioural changes, performance decrement and lack of attendance and re-enrolment in Table 4 (p. 4.12). Some of the psychological and behavioural changes due to lack of fulfilment of expectations were anxiety, disinterest and confusion. Performance plateaued or dropped due to negative disconfirmation. Attendance dropped and students chose alternative institutions if expectations were not met. In addition, three teachers in Study 1 noted that students are generally receptive to learning if the usefulness of what they are learning is explained beforehand ("... it is up to us to explain to them why they are doing something... that often helps... they always understand then why they are doing it'). Also, as students learn, they become adaptive towards existing content and methodology. According to one teacher, students may be willing to adapt to existing curricula even if teachers just listen to their expectations ('... not because their expectation is met but because I have listened to them... They are willing to give me a second chance... they know that I've heard what they have said').

\section{OUTCOMES OF CONFIRMATION AND POSITIVE DISCONFIRMATION}

As Study 2 extends Study 1 , the following results relate to Study 2 only.

\section{STUDENTS}

Regarding effects of confirmation and positive disconfirmation, all students said that they would be happy with the course, teachers and institution, if their expectations were met. This would make them confident in using English (6 students), more motivated to 


\begin{tabular}{|c|c|c|}
\hline $\begin{array}{l}\text { Psychological and } \\
\text { Behavioural Changes }\end{array}$ & $\begin{array}{l}\text { Performance } \\
\text { Decrement }\end{array}$ & $\begin{array}{l}\text { Lack of attendance and } \\
\text { re-enrolment }\end{array}$ \\
\hline $\begin{array}{l}\text { Anxiety } \\
\text { (S1: } S=2, T=1 \text { ) } \\
\text { Disappointment } \\
\text { ( } S 1: S=2, T=1 ; \\
S 2: S=12, T=9 \text { ) } \\
\text { Anger } \\
\text { (S1: } S=2, T=1 \text {; } \\
\text { S2: } S=5, T=1 \text { ) } \\
\text { Disinterest and boredom } \\
\text { ( } S 1: S=3, T=1 ; \\
S 2: S=7, T=8 \text { ) } \\
\text { Lack of attentiveness } \\
\text { ( } 1: S=3, T=1 \text { ) } \\
\text { Failing sick and feeling } \\
\text { discouraged } \\
\text { (S1: } T=1 \text { each) } \\
\text { Stressed } \\
\text { ( } S 2: S=2, T=1 \text { ) } \\
\text { Confused and unstimulated } \\
\text { ( } S 2: S=1 \text { each) } \\
\text { Dominating class } \\
\text { discussions, disruptive } \\
\text { behaviour and talking in } \\
\text { L1 } \\
\text { ( } S 1: T=1 \text { each) } \\
\text { Intimidating other students } \\
\text { (S2: } T=1 \text { ) }\end{array}$ & $\begin{array}{l}\text { Stagnation or drop in } \\
\text { performance }- \text { both } \\
\text { global and skill specific } \\
\text { (S1: } S=2, T=1 \text {; } \\
\text { S2: } S=3, T=4 \text { ) } \\
\text { Lack of student initiatives in } \\
\text { learning } \\
(S 1: T=1)\end{array}$ & $\begin{array}{l}\text { Drop in attendance } \\
\text { ( } S 1: S=2 \text {; } \\
S 2: T=1 \text { ) } \\
\text { Change classes } \\
\text { ( } S 1: S=1 ; \\
S 2: S=5, T=1) \\
\text { Change institutions } \\
\text { (S1: } S=6 ; \\
S 2: S=1 \text { ) } \\
\text { May return to home country } \\
\text { prior to reaching desired } \\
\text { proficiency in English } \\
\text { (S1: } S=1 \text { ). } \\
\text { Negative recommendations } \\
\text { about the institution } \\
\text { (S2: } S=1, T=1 \text { ) }\end{array}$ \\
\hline
\end{tabular}

Table 4 Outcomes of negative disconfirmation elicited from students and teachers $S 1=S t u d y$ i; $\$ 2=$ Study $2 ; \mathrm{S}=$ Student; $T=$ Teachar

learn ( 5 students), attend and enjoy the course ( 2 students each), recommend the institution to prospective students, participate in class, feel comfortable in class and institution (1 student each). Overall, fulfilment of expectations generated positive affective and learning outcomes amongst these students.

\section{TEACHERS}

All teachers also agreed that confirmation and positive disconfirmation had an encouraging effect. Apart from responses similar to students (better attendance, motivated in class and positive recommendations), students thank them for expectation fulfillment ( 3 teachers), show positive attitudes towards target culture and leave with positive learning 
and lifestyle experiences ( 2 teachers), do extra work and regard teachers as friends (1 teacher each).

\section{MOTIVATIONAL CONSEQUENCES OF EXPECTATIONS}

\section{STUDENTS}

Students (6) stated that they would put in more effort and feel responsible for their own learning ( 2 students) if their expectations were met. Motivation would drop if expectations were not met ( 10 students). Approachable teachers and conscientious classmates were important in maintaining motivation ( 2 students).

\section{TEACHERS}

All teachers agreed that expectation fulfilment led to higher motivation. In lower levels students have simple expectations which, when fulfilled, lead to rapid progress and rise in motivation. However, in higher levels, expectations are more complex and progress slower. Students view this as negative disconfirmation or delay in confirmation of expectations and experience motivation loss ( 1 teacher). Students with imminent goals such as a language skill testing exam or university education may not experience a drop in motivation even if their expectations are not met (1 teacher). Sometimes inappropriate learning habits cause negative disconfirmation and lower motivation (1 teacher).

\section{FACTORS AFFECTING SATISFACTION IN LANGUAGE LEARNING}

Due to similarities, teacher and student responses on this issue have been compiled together. All teachers and students agreed that fulfilment of expectations affected general satisfaction with the language learning experience. Amongst other factors affecting satisfaction, accommodation was a major one (12 students, 7 teachers). Students often live with Australian families and a positive environment enhanced language learning by providing situational and cultural experiences and a sense of security. Opportunity to foster long-term friendships (Australians and international students) and learning about their cultures affected satisfaction (12 students, 3 teachers). Institutional help in settling down such as information about the city, transportation, health care facilities, extra curricular activities and travel opportunities affected satisfaction (12 students, 4 teachers). Besides these, culture shock, homesickness, parental pressure and placing the source of learning within or outside themselves also affect satisfaction ( 2 teachers). 


\section{DISCUSSION}

This research was guided by a set of five research questions. The first asked, do students bave pre-conceived expectations about TESOL courses? The results indicate that students in ESOL classes do indeed have a priori expectations about the courses in which they are enrolled. Results indicate that some of these expectations can be very specific and based on the immediate linguistic goals and needs of the students, while others are more generally related to their long-term language use. The next question, what factors shape these expectations?, received a multitude of responses ranging from social, educational and cultural backgrounds to individual differences in students in terms of personality and linguistic needs from both studies discussed here. In relation to the question what are the outcomes of negative disconfirmation of expectations?, the data revealed a variety of outcomes related to behavioural changes, performance and re-enrolment.

The next question, What are the outcomes of positive disconfirmation and confirmation of expectations?, also received a variety of responses related to positive motivational, behavioural and performance related outcomes in Study 2. Finally, responses from Study 2 shed light on the last research question, what other factors affect satisfaction in TESOL programs?, and results indicated that many major issues of learning and living in a foreign country affected satisfaction.

These studies have been able to find an extensive range of responses for each of the research questions. The results indicate that the lack of fulfilment of student expectations can lead to negative behavioural and performance related outcomes. This shows support for the fact that student expectations are indeed an affective variable in SLA. As mentioned before, various other affective factors have been extensively researched in SLA over the years. Student expectations, however, have been a neglected research topic. In the next section we present a model for TESOL student expectations.

\section{MODEL OF EXPECTATION DISCONFIRMATION IN TESOL.}

Based on the results of our studies and to fit the needs of SLA, three aspects have been added to the Expectation Disconfirmation paradigm: factors affecting expectations; effects of confirmation and disconfirmation (positive and negative) of expectations; and other factors affecting satisfaction. The TESOL model is presented in Figure 2. The factors affecting student expectations according to the responses were: age, time spent on the course, cost of education, language learning goals, cultural background, personality traits, previously encountered teaching styles, institutional marketing, informal recommendations, peer expectations and the role of English as an international language, and 


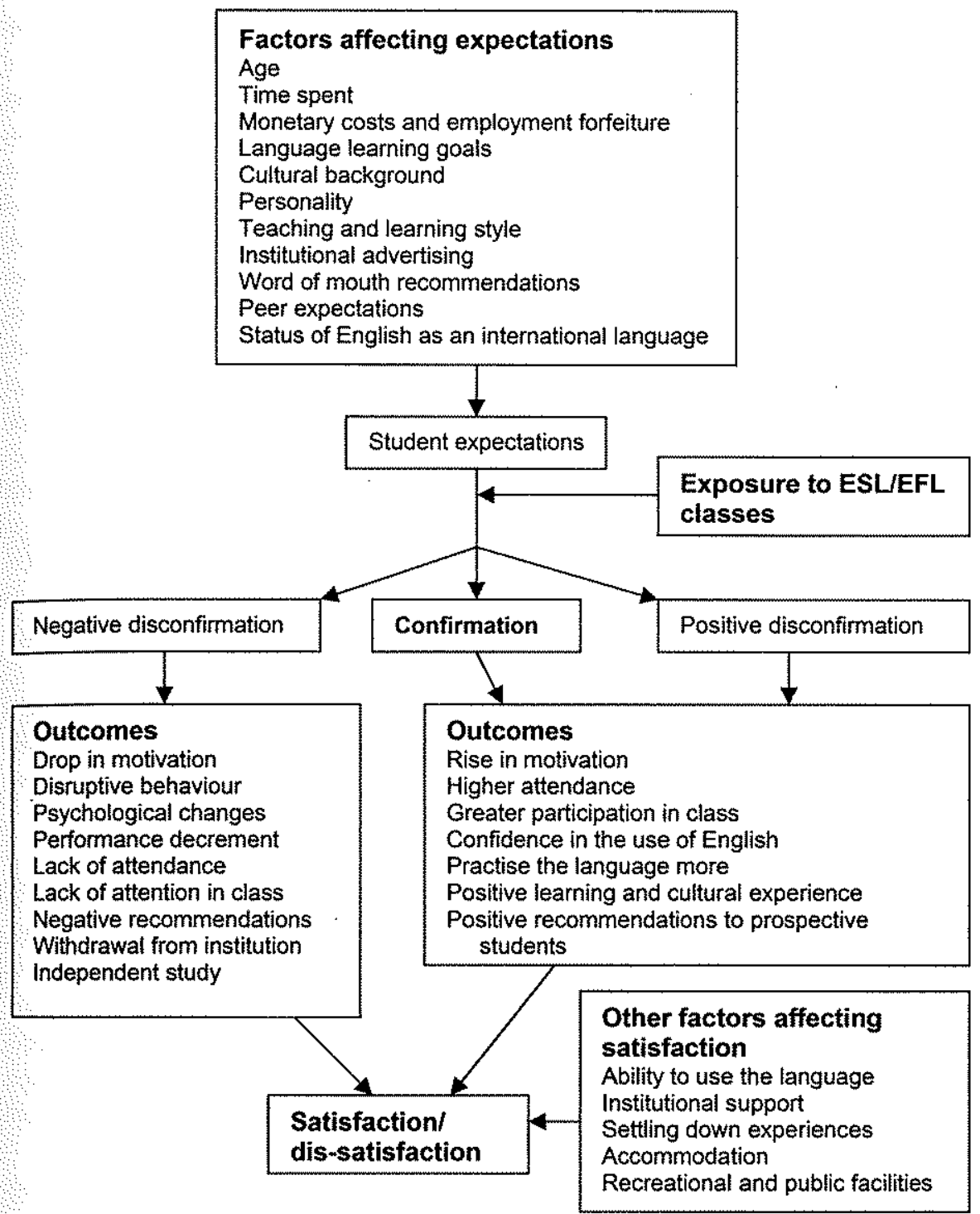

Figure 2 Model of Expectations Disconfirmation in TESOL 
personal learning style. These factors shape expectations which when exposed to TESOL. programs, are confirmed, positively disconfirmed or negatively disconfirmed.

In the case of confirmation and positive disconfirmation, Study 2 showed that students are more motivated to learn, have better attendance and greater participation in class, feel confident in using the language, practise more and request teacher feedback, have a positive attitude towards class, teacher, institution, language learning experience and target culture and convey positive recommendations to prospective students. As the study does not determine whether the intensity of these outcomes changes if the expectation is confirmed or positively disconfirmed, the outcomes are grouped together in the model.

When expectations are not met, several negative consequences occur for the student, course and the educational institution. The outcomes of negative disconfirmation were: drop in motivation, negative and disruptive behavioural and psychological changes, performance decrement, lack of attendance and attention in class, negative recommendations to prospective students, withdrawal from institutions, pursuit of independent study and seeking of teacher feedback. Indeed, dysfunctional and non-productive behavioural patterns amongst language learners have been identified by some researchers (Alsop 1979; Antier 1976; Bassano 1986; Curtin 1979; Gardner et al. 1978), but have not been linked to student expectations. These outcomes may very well be dependent upon the lack of fulfilment of student expectations.

Finally, in addition to expectation fulfillment, other factors that can affect satisfaction with the language learning experience were: effective use of English in day-to-day life, social associations and positive settling down experiences, institutional assistance, accommodation and recreational and public facilities available.

\section{CONCLUSION}

The results show that expectation fulfilment can increase student motivation in TESOL. As mentioned earlier, research on expectations can clarify some ambiguities in motivational research, as some studies on motivation (e.g., Gardner and Santos 1970; Lukmani 1972; Oller et al. 1977a; Oller et al. 1977b) that showed ambiguous results were conducted in settings where learners learnt the language for instrumental rather than integrative reasons. Taking student expectations into account can help broaden motivational research in SLA.

The responses show that students and teachers areaware of the existence of student expectations, the factors affecting them and the outcomes of negative disconfirmation. This further points to the need for research and development of theoretical knowledge 
on student expectations based on learner and practitioner viewpoints. Teachers in general are aware that students come with a variety of expectations that need to be met (or explained why they cannot be met) in order to foster positive learning experiences. They are also aware that course syllabi are not set in stone and need to be constantly modified to meet students' societal and professional needs. Program coordinators can use student expectations to create courses in-tune with student needs, hence retaining students. This may lead to positive word-of-mouth recommendations and result in attracting future students. If the expectations are unrealistic, this can be conveyed to students saving them unnecessary frustration and disillusionment. This research presents important findings regarding student expectations and how it affects language learning. The model presented can help us understand the process of expectation disconfirmation and predict variables shaping expectations and significant outcomes of disconfirmation.

\section{APPENDIX A: PROTOCOL FOR FACILITATED GROUP INTERVIEWS}

\section{TEACHERS}

In your experience, do students have expectations regarding content material or teaching methodology of a course?

Do the students speak about their expectations? If so, when during the term, do they voice their expectations?

What factors may play a role in shaping student expectations?

What happens if expectations are not met? Do you notice any changes in class or students' learning pattern, etc.?

\section{STUDENTS}

Do you have any expectations about what you want to learn?

Do you have any expectations about what methods you want to be taught by?

What factors shapes your expectations? (if no response, use eg.: is it goals for learning the language, family pressure, etc.?)

What do you feel or do if your expectations are not met? 


\section{APPENDIX B: PROTOCOL FOR IN-DEPTH INTERVIEWS}

\section{TEACHERS}

In your experience, do students have expectations from courses they take?

Do student expectations gradually change over time?

Can you think of any variables that may shape student expectations?

What are the outcomes when expectations are fulfilled?

What are the outcomes when students get more than they expected on a certain topic/skill?

What are the outcomes when expectations are not fulfilled?

Does the fulfilment or lack of fulfilment of students' expectations have any bearing on motivation levels?

Does expectation fulfilment affect students'. overall satisfaction with language learning?

Are there other variables that affect satisfaction?

\section{STUDENTS}

Do you have any expectations regarding the content and the teaching methodology of the courses you take?

What issues shape your expectations?

What do you feel when your expectations are met?

What do you feel when you get more than you expected?

What do you feel when your expectations are not met?

Does the fulfilment or lack of fulfilment of expectations affect your motivation?

How much of a role does expectation fulfilment plays in your overall satisfaction in language learning?

Are there other variables that affect satisfaction? 


\section{ENDNOTES}

1 This article is part of Sarbari Bordia's doctoral thesis. The authors would like to thank Prashant Bordia for his advice on content and editorial issues relating to the manuscript.

2 Non-numerical Unstructured Data (NUD-IST), power version, revision 4.0. See Richards and Richards (1981).

3 The International English Language Testing System (IELTS) is used widely in Australia as the benchmark exam for English skills of international students entering tertiary education.

\section{REFERENCES}

Alsop, Thomas. 1979. 'A need to discover how students have been taught foreign languages'. Foreign language annals 12: 197-199.

Antier, Maurice. 1976. 'Language teaching as a form of witchcraft', ELT journal 31: 1-10.

Au, Shun. 1988. 'A critical appraisal of Gardner's social-psychological theory of second-language (L2) learning'. Language learning 38: 75-100.

Bassano, Sharron. 1986. 'Helping learners adapt to unfamiliar methods'. ELT journal 40:13-19. Belmechri, Faiza; Hummel, Kristen. 1998. 'Orientations and motivation in the acquisition of English as a second language among high school students in Quebec City'. Language learning 48: 219-244.

Clément, Richard; Kruidenier, Bastian. 1985. 'Aptitude, attitude, and motivation in second language proficiency: A test of Clément's model'. Journal of language and social psychology 4:21-37.

Crookes, Graham; Schmidr, Richard. 1991. 'Motivation: Reopening the research agenda'. Language learning 41: 469-512.

Csizer, Kata; Dörnyei, Zoltan. 2005. 'Language learners' motivational profiles and their motivated learning behaviour'. Language learning 55: 613-659.

Curtin, John. 1979. 'Attitudes to language learning: the adult student'. ELT journal 33: 281-284. Dörnyei, Zoltan. 1994. 'Motivation and motivating in foreign language classroom'. The modern language journal 78: 273-284.

Dörnyei, Zoltan. 2005. The psychology of the language learner: Individual differences in second language acquisition. Mahwah, NJ: Erlbaum.

Frank, Jerome. 1968. 'The influence of patients' and therapists' expectations on the outcome of psychotherapy'. British journal of medical psychology $41: 349$-356.

Gardner, Robert; Lambert, Wallace. 1959. 'Motivation variables in second language acquisition'. Canadian journal of psychology 13: 266-272.

Gardner, Robert; Lambert, Wallace. 1972. Attitudes and motivation in second language learning. Rowley, Mass.: Newbury House.

Gardner, Robert; Santos, E. 1970. 'Motivational variables in second langlaage acquisition: a Philippine investigation'. Research bulletin 149. London, Ontario: Department of Psychology, University of Western Ontario. 
Gardnex, Robert; Smythe, Padric; Clément, Richard. 1978. 'Intensive second language study in a bicultural milieu: An investigation of attitudes, motivation and language proficiency'. Language learning 29: 305-320.

Gass, Susan. 2001. 'Innovations in second language research methods'. Anntsal review of applied linguistics 21: 221-232.

Lalonde, Richard; Gardner, Robert. 1984. 'Investigating a causal model of second language acquisition: where does personality fit?' Canadian journal of behavioural science 16 : $224-237$.

Lukmani, Yasmeen. 1972. 'Motivation to learn and language proficiency'. Language learning 22: $261-273$.

Martin, Susan. 2003. 'Using SERVQUAL in health libraries across Somerset, Devon and Cornwall'. Health Information and libraries journal 20: 15-21.

Masgoret, Ann-Marie; Gardner, Robert. 2003. 'Attitudes, motivation, and second language learning: A meta-analysis of studies conducted by Gardner and associates'. Language learning 53: $123-163$.

McKinney, Vicki; Yoon, Kanghyun; Zahedi, Fatemeh. 2002. 'The measurement of web-customer satisfaction: An expectation and disconfirmation approach'. Information systems research 3: $296-315$.

McNamara, Timothy. 2001. 'The roots of applied linguistics in Australia'. Australian review of applied linguistics 24: 13-29.

Miller, John 1977. 'Studying satisfaction, modifying models, eliciting expectations, posing problems, and making meaningful measurements'. In Conceptualization and measurement of consumer satisfaction and dissatisfaction edited by Hunt, Keith. Bloomington: School of Business, Indiana University.

Noyes, Robert; Levy, Marvin; Chase, Charle; Udrey, Richard. 1974. 'Expectation fulfilment as a meastire of patient satisfaction'. American journal of obstetrics and gynaecology 118 : 809-814.

Nunan, David 1994. Research methods in language learning. Cambridge, UK: Cambridge University Press.

Nunan, David. 2001. 'English as global language'. TESOL quarterly 35 (4): 605-606.

Oller, John; Baca, Lori; Vigil, Alfred. 1977a. 'Attitudes and attained proficiency in ESL: A sociolinguistic study of Mexican Americans in the southwest'. TESOL quarterly 11: 173-183.

Oller, John; Hudson, Alan; Liu, Phyllis. 1977b. 'Attitudes and attained proficiency in ESL: A sociolinguistic study of native speakers of Chinese in the United States'. Language learning 27: 1-27.

Oxford, Rebecca; Shearin, Jill. 1994. 'Language learning motivation: Expanding the theoretical framework'. The modern language journal 78: 12-28.

Ozge, Uzan. 2001. 'Patient satisfaction with nursing care at a university hospital in Turkey'. Journal of nursing care quality $16 ; 24-33$. 
Parasuraman, A; Zeithaml, Valarie; Berry, Leonard. 1985. 'A conceptual model of service quality and its implications for future research'. Journal of marketing 49: 41-50.

Parasuraman, A; Zeithaml, Valarie; Berry, Leonard. 1988. 'SERVQUAL: A multiple item scale for measuring consumer perceptions of service quality'. Journal of retailing 64: 12-40.

Richards, Lyn; Richards, Tom 1981. NUDIST: A computer assisted technique for thematic analysis of unstructured data. Bundoora, Vic.: Dept. of Sociology, La Trobe University.

Ross, Caroline; Frommelt, Gayle; Hazelwood, Lisa; Chang, Rowland. 1987. 'The role of expectations in patient satisfaction with medical care'. Journal of bealth care marketing 7: 16 26.

Ross, Catherine; Wheaton, Blaire; Duff, Raymond. 1981. 'Client satisfaction and the organization of medical practices: Why time counts' Journal of health and social behavior 22: 243-255.

Santos, Jessica; Boote, Jonathan. 2003. 'A theoretical exploration and model of consumer expectations, post-purchase affective states and affective behaviour'. Journal of consumer behaviout 3: $142-156$.

Spolsky, Bernard. 2000. 'Anniversary article: Language motivation revisited'. Applied linguistics 21: 157-169.

Tan, Kay; Kek, Sei. 2004. 'Service quality in higher education using an enhanced SERVQUAL approach'. Quality in bigher education 10:17m24.

Tremblay, Paul; Gardner, Robert; Heipel, Gerwin. 2000. 'A model of the relationships among measures of affect, aptitude, and performance in introductory statistics'. Canadian journal of behavioural science $32: 40-48$.

Cite this article as: Bordia, Sarbari; Wales, Lynn; Pittam, Jeffery; Gallois, Cindy.'Student expectations of TESOL programs: Student and teacher perspectives'. Australian Review of Applied Linguistics 29 (1): pp. 4.1-4.21. D01: $10.2104 /$ aral0604. 